\title{
MOBILIDADE POPULACIONAL NA REGIÃO METROPOLITANA DE PORTO ALEGRE NOS ANOS 90
}

Maria de Lourdes Jardim

TANYa M. DE Barcellos

\begin{abstract}
Resumo: Este texto avalia as tendências da mobilidade populacional na Região Metropolitana de Porto Alegre - RMPA nos anos 90, em relação com seu perfil econômico recente. Para tanto, explora os dados do Censo de 2000, em termos de origem/destino da migração intrametropolitana e fluxos pendulares. Palavras-chave: Migração. Mobilidade pendular. Metrópoles.

Abstract: This paper analyses the main trends of evolution of the population movements in the Porto Alegre Metropolitan Area, and its relationships with recent economic changes. It is based on the 2000 Demographic Census, and it focuses the origin and destination of population flows.

Key words: Migration. Population mobility. Metropolitan areas.
\end{abstract}

$\mathrm{E}$ ste trabalho integra-se ao campo de estudos sobre as mudanças que acompanham o processo de reestruturação econômica e globalização que incidem sobre as configurações urbanas, especialmente nas áreas metropolitanas. Harvey (1992) chama a atenção para algumas características da globalização, como a "compressão espaço/tempo", que flexibiliza as escolhas de localização das atividades econômicas, promovendo uma competição maior entre lugares. As possibilidades de desconcentração que se divisam alteram substancialmente os movimentos dos capitais e das populações. Observa-se o surgimento de novas territorialidades, que emergem de rearticulações na produção industrial e agrícola e na organização das atividades de prestação de serviços e provocam uma nova dinâmica migratória. Nesse contexto, a grande cidade

tem que ser entendida levando-se em conta os nexos que se estabelecem com as cidades do entorno, alcançando às vezes outras regiões, que se traduzem em aglomerações regionais, uma vez que os complexos urbanos extravasam as cidades, conectando-se de maneira integralizada (BAENINGER, 1997).

O texto trata especificamente da mobilidade populacional - particularmente da intrametropolitana enquanto elemento crucial na compreensão da formação e consolidação de novos espaços urbanos. O foco volta-se para a Região Metropolitana de Porto Alegre - RMPA nos anos 90, para examinar o fenômeno da mobilidade em sua relação com as recentes transformações do perfil econômico da região. Trata-se mais especialmente do movimento de reconcentração da indústria no espaço metropolitano - fato que se verifica nos anos 90, após um período em que era perceptível uma tendência à desconcentração das atividades econômicas, sobretudo da indústria. Também levouse em consideração o aumento da importância do comércio fora da sede metropolitana. ${ }^{1}$ A partir dos dados do Censo Demográfico 2000, foram dimensionados e caracterizados em termos de origem/destino: a imigração para a 
metrópole, os fluxos intrametropolitanos e os movimentos pendulares. Desse modo foi possível formar um panorama da dinâmica demográfica e de seu papel na conformação do espaço metropolitano.

\section{SOBRE A FORMAÇÃO E EXPANSÃO URBANA}

É importante demarcar alguns pontos relativos à formação histórica da área que hoje constitui a RMPA, que são importantes para a compreensão das características básicas assumidas pela configuração metropolitana no período recente.

Primeiramente, é necessário voltar ao final do século 18 e início do 19, quando Porto Alegre já se ressalta como porto de saída dos excedentes produzidos pela agricultura de subsistência dos colonos açorianos localizados em Viamão, Gravataí e Santo Antônio da Patrulha e ao longo dos vales dos rios Taquari e Jacuí, em Cachoeira, Rio Pardo, Triunfo, Santo Amaro ${ }^{2}$ e Taquari (CARRION, 1989; ORTH; ALVES, 2001). A partir de 1824, a imigração alemã foi o centro de formação de novos núcleos de produção colonial, tendo por base São Leopoldo, ao norte de Porto Alegre, no vale do rio dos Sinos, e representou um momento fundamental no processo de constituição da região.

Entre Porto Alegre e as colônias, estabeleceu-se intenso comércio - fato que, segundo Singer (1968), criou as bases de forte processo de industrialização, que levou a cidade a assumir a liderança industrial do Estado a partir de 1920. A indústria que aí se desenvolveu apresentou desde cedo uma estrutura diversificada e voltada para o mercado local.

Nesse comércio, predominou o transporte fluvial até o fim do século 19, quando surgiu outro fato relevante que marcou o desenvolvimento da região: a construção de uma ferrovia, que pretendia responder à grande expansão da produção local. Em 1874, foi concluído o trecho entre Porto Alegre e São Leopoldo, que, em 1876, alcançou Novo Hamburgo; em 1903, Taquara; e, em 1924, Canela (CARRION, 1989).

Assim, formou-se um eixo em direção ao norte, que seguia a via férrea e depois a BR-116, concluída no final dos anos 40, ligando São Leopoldo e Novo Hamburgo a Porto Alegre. Desta forma, desde meados do século 20 até o início dos anos 70, esse eixo concentrou a ocupação urbana e industrial da atual RMPA. O desenvolvimento industrial que se estendeu para fora de Porto Alegre, seguindo a direção das antigas colônias, deu lugar a uma expansão ur- bana com formato distinto do clássico "centro-periferia" que caracteriza grande parte das metrópoles brasileiras (Mapa 1). De tal modo ocorreu a expansão urbana que se configurou uma conformação "multipolar", até hoje claramente identificável, com Porto Alegre no centro da parte sul da região e São Leopoldo e Novo Hamburgo polarizando o norte (CASTELLO BRANCO, 2003).

Além desse vetor, foram importantes na conformação da região os núcleos urbanos antigos em Viamão e Gravataí, situados respectivamente a leste e nordeste de Porto Alegre.

Em termos econômicos, além de Porto Alegre e de Novo Hamburgo e São Leopoldo, no Vale dos Sinos, começaram a se sobressair outros centros industriais, como Canoas. Nesse caso, foi fundamental a instalação da Refinaria Alberto Pasqualini, que ensejou o desenvolvimento de um parque industrial já diversificado em 1970 e que cresceu com a presença de vários ramos dinâmicos, como química, material elétrico e de comunicações, metalurgia e mecânica. Já Novo Hamburgo e São Leopoldo formaram uma estrutura industrial muito especializada no ramo coureiro-calçadista, junto com outras localidades do norte metropolitano - muito embora já tenham atualmente ampliado as atividades de comércio e serviços, constituindo-se em pólos regionais.

Na década de 70, a construção da BR-290 - que liga Porto Alegre à BR-101 - também configura um fator a ser destacado no processo de expansão da metrópole, pois favoreceu a implantação de indústrias no eixo leste-nordeste, em Gravataí e Cachoeirinha (Mapa 1).

Um dos efeitos dessa dinâmica foi um movimento crescente de concentração populacional na RMPA: em 1940, nela estavam $12 \%$ da população do Estado - proporção que alcançou os 23\% em 1970, 29\% em 1980, atingindo 33\% em 1991 (CARRION, 1989; BARCELLOS, 2002). Na última década, o incremento já não foi tão significativo, estabilizando a participação da RMPA na população do RS em 34\% (BARCELLOS, 2002).

Mesmo com menor crescimento e perdendo peso demográfico, a sede metropolitana ainda concentra grande parcela da população da região, numa proporção que foi de quase $40 \%$ em 2000. Em contraposição, os demais municípios ampliaram sua fatia na composição da população da metrópole, passando de $13 \%$ para 15\% (BARCELLOS, 2002).

Há pelo menos duas décadas, o crescimento demográfico metropolitano já vem se concentrando no entorno imediato de Porto Alegre e em algumas localidades pequenas situadas no Vale dos Sinos, na região da produção coureiro- 


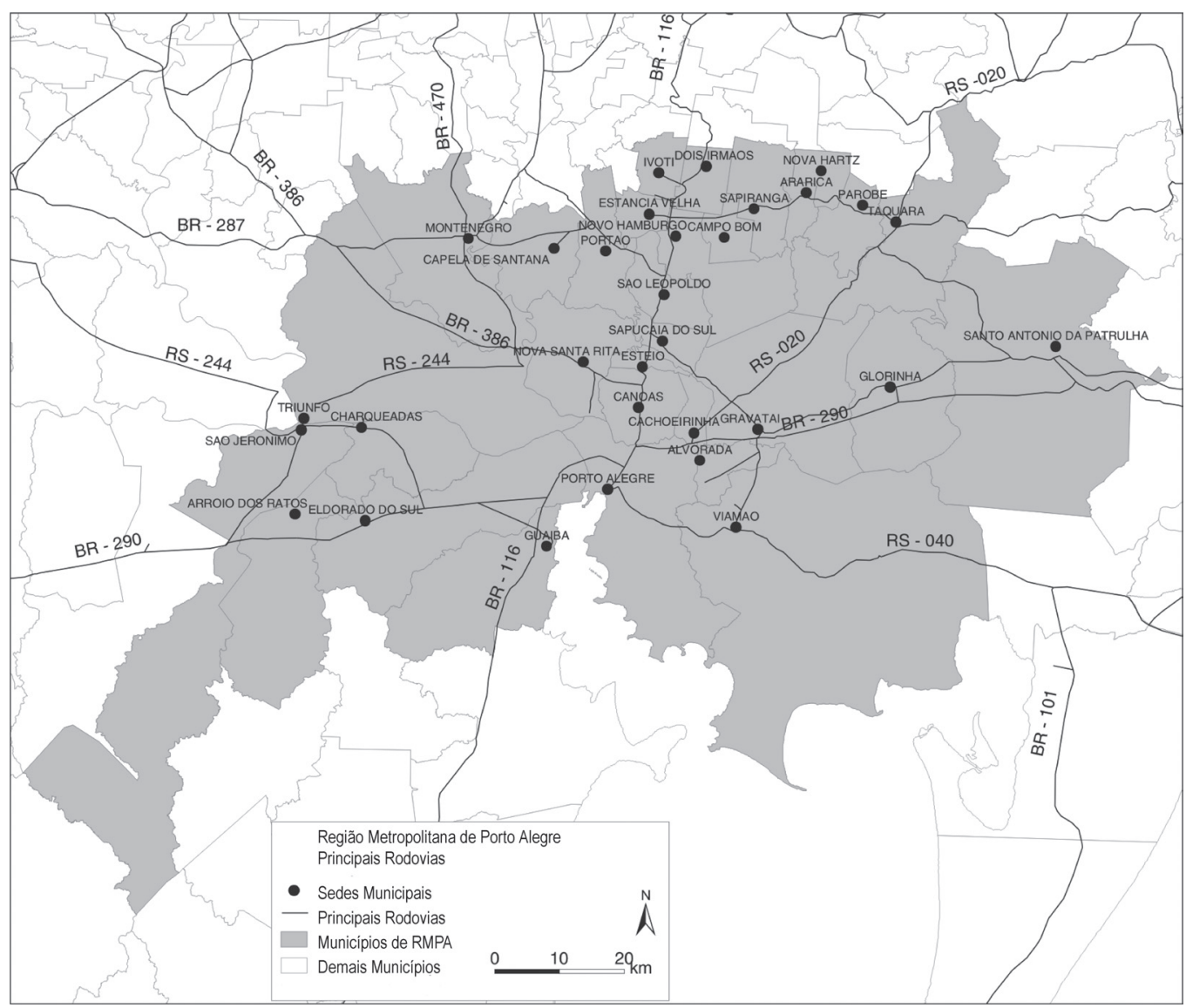

Fonte: Secretaria da Coordenação e Planejamento, Metroplan, Daer.

calçadista do Estado. Entre 1991 e 2000, a população metropolitana aumentou em média $1,7 \%$ ao ano - taxa que alcança os 2,2\% quando se exclui o núcleo. Nas localidades periféricas da capital, o crescimento superou os $5 \%$ ao ano em Nova Santa Rita, município desmembrado de Canoas, e quase alcançou os 5\% em Eldorado do Sul. Em Alvorada e Viamão, tradicionais cidades-dormitório, as taxa foram superiores a 2,5\%. Ainda no entorno de Porto Alegre, deve ser destacado o incremento populacional de Gravataí, sede do complexo automotivo da General Motors, que foi de 2,9\% ao ano, bem acima da média metropolitana. Na região do Vale dos Sinos, as cifras são igualmente impressionantes em alguns casos, muito embora se trate de municípios de pequeno porte, como Nova Hartz e Dois Irmãos, onde a taxa de incremento também se aproximou dos
5\%; e Parobé, Ivoti e Araricá (desmembrado de Sapiranga), onde foi superior a 3\% ao ano (Mapa 2).

Porto Alegre perdeu peso demográfico e reduziu seu ritmo de incremento populacional. Sua contribuição à formação da população urbana gaúcha diminuiu de 21,43\%, em 1980, para 18,06\%, em 1991, e para 16,36\%, em 2000. A taxa de crescimento demográfico, que era de $2,4 \%$ ao ano na década de 70, ficou em apenas 1,1\% entre 1980 e 1991 (BARCELLOS, 2002), caindo para 0,9\% ao ano entre 1991 e 2000: bem abaixo, inclusive, da taxa de incremento populacional média do Rio Grande do Sul, que na última década foi de 1,2\% ao ano (Mapa 2). A dinâmica demográfica da capital reflete as transformações relacionadas aos processos de desconcentração da produção industrial como parte da redução das vantagens locacionais nas grandes 
aglomerações e de periferização da moradia da força de trabalho.

Os municípios da RMPA que apresentaram taxa de crescimento demográfico inferior ao incremento médio observado na região entre 1991 e 2000 (1,7\% a.a.) foram, além de Porto Alegre: Arroio dos Ratos, Campo Bom, Canoas, Esteio, Novo Hamburgo, Santo Antônio da Patrulha, São Jerônimo e São Leopoldo (Mapa 2). Deve-se ressaltar que também os pólos da área coureiro-calçadista, São Leopoldo e Novo Hamburgo, estão reduzindo a intensidade de seu incremento demográfico, enquanto grande parte dos municípios da região cresce a um ritmo mais acentuado, indicando talvez um movimento semelhante ao que já vem ocorrendo na capital, que expulsa população para municípios limítrofes.

\section{A ECONOMIA METROPOLITANA NO PERÍODO RECENTE}

A concentração demográfica da RMPA expressa uma concentração econômica, que pode ser avaliada pela participação da região na composição do Valor Adicionado Bruto - VAB do Estado. Embora tenha caído entre 1990 e 1998, o peso do produto metropolitano no VAB gaúcho aumentou no final da década, superando os $40 \%$. Na indústria, a contribuição de 51,3\% à formação desse setor, em 1990, caiu até 1998 , recuperando-se depois disso, quando alcançou os $54,7 \%$, em 2000 . No que se refere ao setor terciário (comércio e demais serviços), a economia metropolitana representou em torno de $41 \%$ do produto gerado no Rio Grande do Sul por esse segmento naqueles anos. O comércio teve

MAPA 2

Taxa Média de Crescimento Anual da População

Região Metropolitana de Porto Alegre - 1991/2000

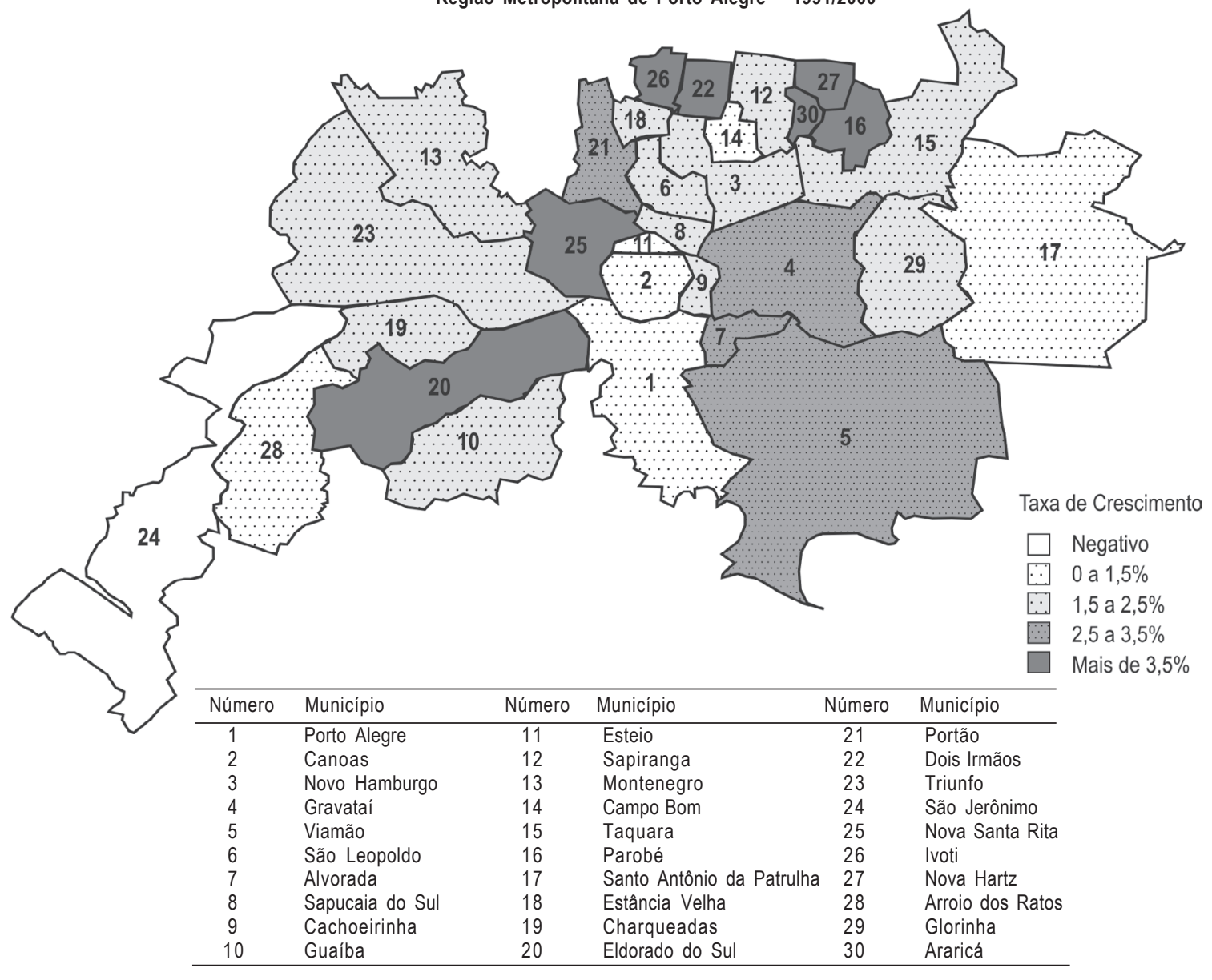

Fonte: IBGE. 
forte incremento de participação no período, passando de 47,3\%, em 1990, para 54,3\%, em 2000 (Tabela 1).

No interior do espaço metropolitano, podem ser identificados alguns diferenciais importantes no que diz respeito às características da atividade econômica, de modo a permitir sua organização em sub-regiões (Mapa 3). Alonso (2003, p. 5), em estudo preliminar sobre os efeitos da reestruturação nas formações metropolitanas de Porto Alegre e Curitiba, compõe o seguinte conjunto: ${ }^{3}$

A RMPA 1 ocupa, predominantemente, a parte norte da RMPA, ao longo da BR - 116. Tem uma estrutura econômica com forte presença industrial, que pode ser considerada especializada na cadeia coureiro-calçadista. A rede urbana deste recorte é polarizada por dois centros, São Leopoldo e Novo Hamburgo. A RMPA 2, localizada na parte sul da RMPA, sedia a capital do Estado e tem uma formação econômica distinta da anterior, na medida que apresenta um setor industrial diversificado e de maior porte, tanto no agregado, quanto no número de grandes plantas. Diferencia-se ainda por reunir uma oferta maior de serviços, mais complexa e mais sofisticada. A RMPA 3 está localizada na parte sudeste da RMPA, não tem relevância econômica nem urbana, sendo constituida por apenas três pequenos centros. É metropolitana apenas por estar fisicamente muito próxima da mancha metropolitana. A RMPA 4 é formada por três municipios localizados na parte oeste da RMPA. Sua principal característica é sediar a planta do Pólo Petroquímico do Sul (Triunfo). Faz parte deste recorte também o município de Montenegro que possui um parque industrial mais diversificado situado no principal eixo de expansão da RMPA, no caminho para Lajeado, Estrela, Teutônia, Santa Cruz do Sul e Venâncio Aires. Por fim, a RMPA 5 é constituida somente pelo municipio de Santo Antônio da Patrulha, um dos quatro primeiros criados no RS. Localiza-se na parte leste da RMPA, não tem expressão econômica. Tem uma estrutura econômica peculiar para o padrão metropolitano, baseada na histórica produção de cana de açúcar, produção de bens a partir deste produto agrícola.

Na última década, observam-se algumas mudanças importantes na estrutura produtiva metropolitana. Entre 1990 e 1998, houve uma redução significativa da participação relativa do setor industrial no conjunto da produção, tendo como contrapartida um avanço do setor de serviços. Já no período que vai de 1999 a 2001, a produção industrial recuperou posição, e verificou-se uma queda do setor de serviços na composição da produção metropolitana (ALONSO, 2003).

Em termos do comportamento do emprego, embora nessa última década tenha havido um saldo positivo no confronto entre a queda do emprego industrial e o crescimento dos postos de trabalho nas atividades terciárias, verificou-se um crescimento da população economicamente ativa - PEA, que ultrapassou esses excedentes, redundando em índices relevantes de desemprego (FEE, 2003).

A indústria sofreu profundo processo de ajuste (fusões, terceirização de serviços e introdução de inovações tecnológicas), tendo em vista a reestruturação produtiva internacional, com seus desdobramentos no país, e a política econômica interna que, adequando-se às exigências do Fundo Monetário Internacional - FMI, passou a priorizar os princípios liberais de abertura comercial e redução do tamanho do Estado (ALONSO, 2003).

TABELA 1

Participação do Valor Adicionado Bruto (VAB) no VAB Total, por Setor da Economia Região Metropolitana de Porto Alegre - 1990-2000

Em porcentagem

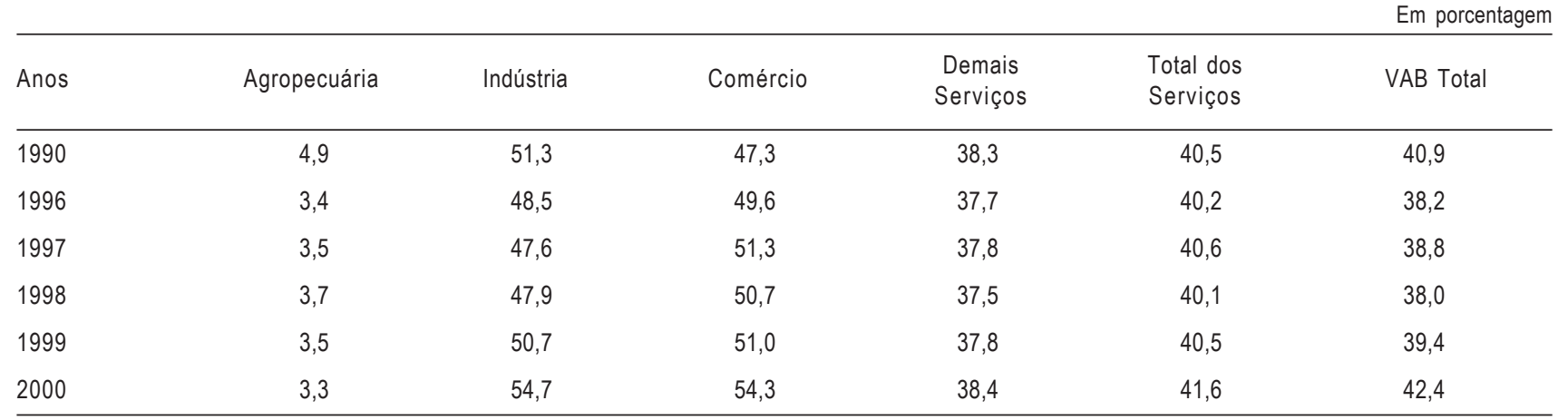

Fonte: FEE/Núcleo de Contabilidade Social. 


\section{MAPA 3}

Divisão da Região Metropolitana de Porto Alegre em Sub-Regiões

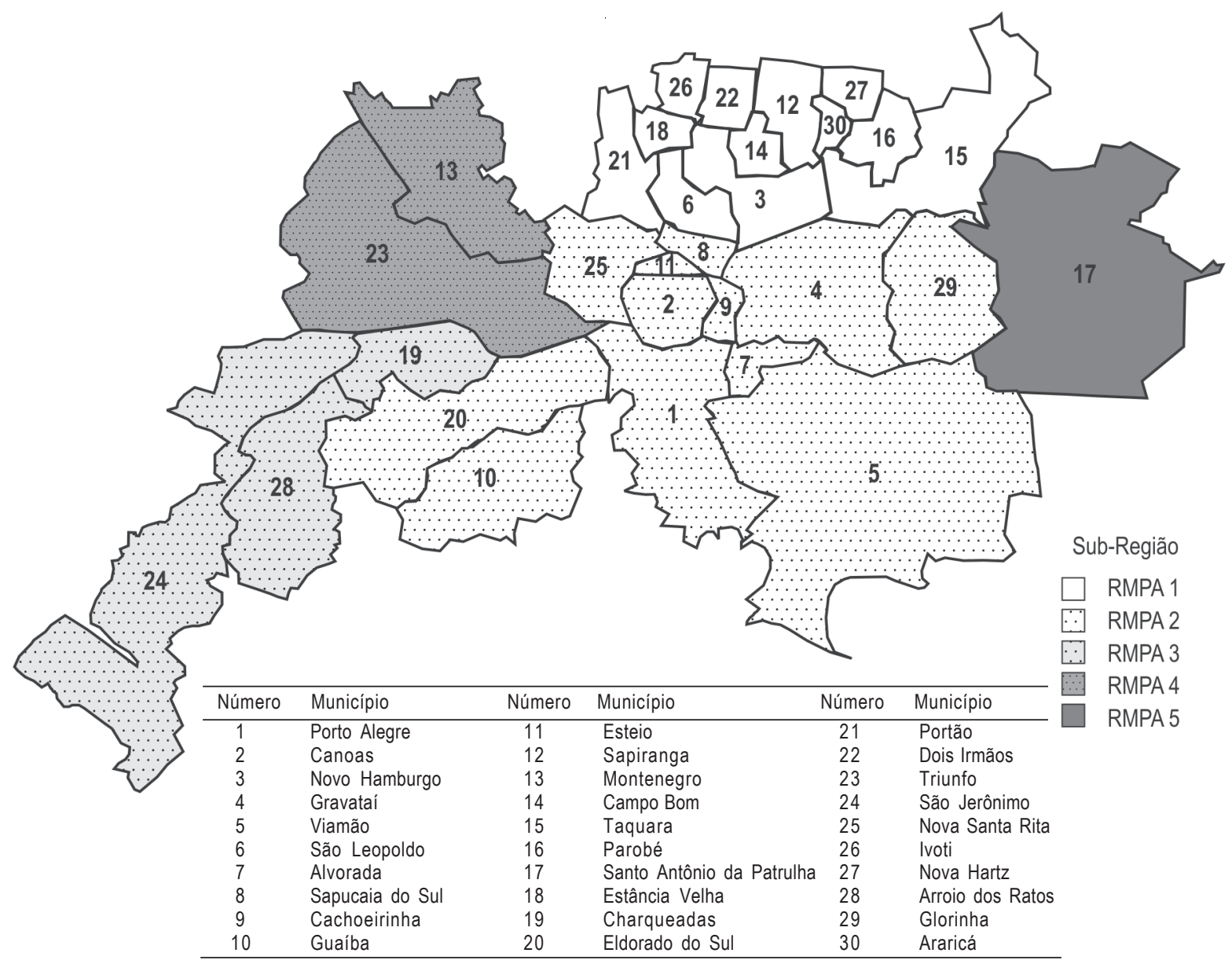

Fonte: Alonso (2003).

Esse quadro de mudanças estruturais apresentou efeitos no território. Após um período em que se podia observar uma tendência à desconcentração das atividades econômicas - principalmente as industriais - a década de 90 trouxe sinais de um movimento de reconcentração da indústria no espaço metropolitano. Desde o início da década, já se percebia que, quando fosse iniciado um novo ciclo de investimentos industriais, as formações metropolitanas de "tamanho médio" (Porto Alegre, Curitiba e Belo Horizonte) ganhariam espaço nas escolhas locacionais. Também no caso do Rio Grande do Sul, havia indícios de uma possível retomada do processo de concentração industrial no âmbito da aglomeração metropolitana. Nos anos 90, mais especificamente a partir de 1999, houve efetivamente uma reversão na tendência à desconcentração industrial (ALONSO, 2003).
O aumento da concentração industrial na RMPA não foi generalizado para os diferentes segmentos da indústria. Na verdade, ele se deve ao crescimento de algumas poucas divisões, afetando sobretudo alguns espaços dentro da metrópole.

No complexo agroindustrial, ${ }^{4}$ há duas divisões que elevaram sua produção na RMPA: a de Bebidas (cervejas e refrigerantes), que se concentra na RMPA 2, sobretudo em Porto Alegre, e passou por profundo ajuste nas suas empresas; e a cadeia de Couro e Calçados, que volta a ampliar sua produção no Vale dos Sinos, depois do movimento de dispersão para fora dos limites da RMPA durante os anos 80 (ALONSO, 2003).

As divisões de Material de Transporte e Material Eletrônico e de Aparelhos e Equipamentos de Comunicações 
também apresentaram expansão na RMPA. A primeira experimentou o maior avanço na produção industrial metropolitana, como resultado, em grande parte, do início das operações do Complexo Automotivo de Gravataí (General Motors), em meados de 2000.

A divisão de Produtos Químicos, cuja cadeia na RMPA sofre forte influência das atividades de "refino de petróleo", aumentou consideravelmente sua produção na RMPA (Canoas e Triunfo). Deve ser mencionada, por fim, maior presença, na RMPA, de Produtos Farmacêuticos e Veterinários, que já apresentava forte concentração na região, particularmente no município de Porto Alegre (ALONSO, 2003).

Nas sub-regiões que compõem a metrópole gaúcha, verificou-se que a RMPA 1 - onde a produção de artigos de couro e calçados é predominante em todos os municípios - manteve sua participação no conjunto do Estado, em todos os setores, nos anos 90. Na década de 90, persistiu a tendência à perda relativa da função industrial exercida historicamente por São Leopoldo e Novo Hamburgo. Outras localidades, como Dois Irmãos e Ivoti, elevaram sua participação na produção industrial do Estado, absorvendo, em certa medida, a produção industrial antes concentrada naqueles dois municípios.

A RMPA 2, que abrange a parte sul da RMPA e tem Porto Alegre como centro principal, secundada por Canoas e Gravataí, tem um perfil econômico diversificado tanto do ponto de vista industrial quanto de serviços. A produção industrial, o movimento comercial e o de serviços dessa subregião é muito superior ao da RMPA 1. É nela que aparecem mais nitidamente as mudanças do ajuste procedido nos anos 90. A indústria dessa parcela da RMPA, que teve queda de participação no produto industrial do Rio Grande do Sul entre 1985 e 1998, voltou a crescer - o que indica um processo de reconcentração geográfica de suas atividades. Esse resultado derivou de alguns grandes investimentos localizados nessa área, especialmente em Canoas e Gravataí. Foi ainda muito importante, nessa sub-região, o incremento do setor de serviços, capitaneado pelas atividades do comércio de mercadorias - o que expressa a centralidade exercida por Porto Alegre e ainda a ampliação da capacidade polarizadora de Canoas, cidade antes muito dependente do comércio da capital. Avanços menores, mas importantes do ponto de vista local, registraram-se no comércio de Esteio, Cachoeirinha e Alvorada (ALONSO, 2003).

A RMPA 3, assim como a RMPA 5, não experimentou mudanças significativas nos anos 90. Constituída por três municípios (Arroio dos Ratos, Charqueadas e São Jerônimo), situa-se numa área "quase deprimida" do ponto de vista econômico. Embora o município de Charqueadas seja sede de um "enclave industrial" representado pela antiga planta da empresa estatal Aços Finos Piratini, que foi privatizada pelo Grupo Gerdau e sofreu reestruturação, o empreendimento não trouxe reflexos relevantes para a renda local (ALONSO, 2003).

A RMPA 4, onde se verifica predominância das atividades industriais na estrutura econômica, foi a sub-região que apresentou o maior aumento de participação no produto estadual. Triunfo - município que sedia o Pólo Petroquímico, empreendimento que recebeu investimentos nos anos 90 - duplicou sua capacidade instalada; e Montenegro - que tem certa tradição industrial - ganhou espaço no contexto industrial do Rio Grande do Sul - especialmente em função do crescimento do segmento processador de aves para consumo interno e exportação (ALONSO, 2003).

A RMPA 5, constituída pelo município de Santo Antônio da Patrulha, tem um peso pequeno na economia estadual e não apresentou grandes alterações na participação do seu produto na formação do Produto Interno Bruto - PIB gaúcho. Não obstante, deve ser mencionada a redução da importância das atividades agropecuárias na economia local, em função da desarticulação da produção de cana-de-açúcar, que se concentrava nesse município. No setor industrial, houve queda na produção de alimentos e aumento relevante na presença do ramo coureiro-calçadista, praticamente inexistente até os anos 80 - o que significa uma transformação estrutural no parque industrial local.

\section{CARACTERÍSTICAS DA MOBILIDADE POPULACIONAL NO ESPAÇO DA METRÓPOLE}

Durante a década de 90, a migração com destino à RMPA originou-se majoritariamente na própria região ou no interior do Rio Grande do Sul, ou seja, ela foi predominantemente de caráter interno. Os fluxos vindos do resto do país não tiveram grande significado na dinâmica demográfica da metrópole gaúcha e diminuíram no período 1991-2000: representavam cerca de $14 \%$ do total de migrantes computados pelo levantamento censitário de 1991, reduzindo-se para $13 \%$ em $2000.5^{5}$ Os deslocamentos intrametropolitanos, em detrimento dos procedentes de outras localidades do Estado, vêm aumentando sistematicamente seu peso, passando de 34\% do total, em 1980, a 42\% em 1991, e a $47 \%$ em 2000, seguindo a tendência encontrada em outras metrópoles nacionais (Gráfico 1). 


\section{GRÁFICO 1}

Migrantes de Cinco Anos ou Mais (1), segundo Local de Residência Anterior

Região Metropolitana de Porto Alegre - 2000

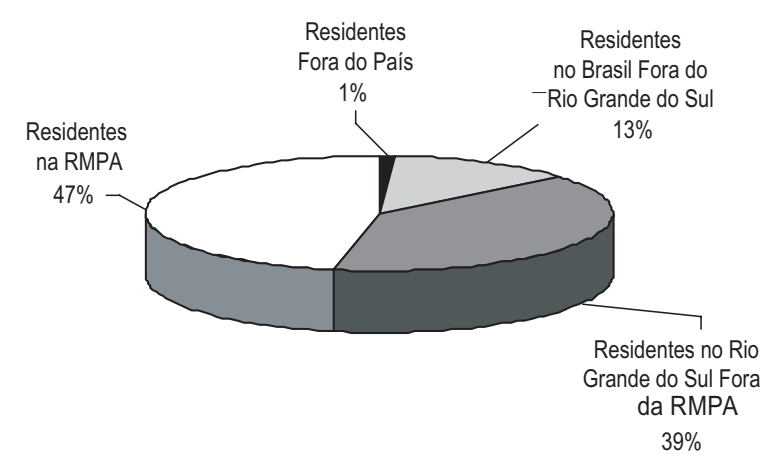

Fonte: IBGE. Censo Demográfico 2000.

(1) Foram consideradas migrantes as pessoas com cinco anos ou mais que, na data da entrevista, residiam há menos de cinco anos no município.

Quando a migração intra-metropolitana é desagregada em sub-regiões, sobressai a concentração de fluxos procedentes da e dirigidos à sub-região polarizada por Porto Alegre - a RMPA 2 - que supera, nos dois casos, os 70\%. Essa sub-região, com a concentração não só de indústrias, mas especialmente de comércio e de serviços, constitui o espaço que apresenta as maiores condições de atratividade na RMPA. No balanço entre saída e entrada de migrantes, essa sub-região terminou por apresentar um saldo negativo, em função dos resultados de Porto Alegre e Canoas. A RMPA 1 aparece em segundo lugar como origem e des- tino de fluxos populacionais. Durante os anos 90, caiu de $79,4 \%$ para $74,2 \%$ a proporção de migrantes que se deslocaram para a RMPA 2, em favor da RMPA 1, indicando que os fatores atrativos naquela área estavam se ampliando. Provavelmente esse fenômeno se relaciona com a dinâmica da indústria coureiro-calçadista, que é grandemente absorvedora de mão-de-obra e manteve sua fatia na economia gaúcha. A diferença entre emigração e imigração, nesse caso, foi positiva (Tabela 2).

As trocas líquidas entre imigração e emigração nos municípios da RMPA mostram aspectos da realidade metropolitana que acompanham tendências identificadas em outras metrópoles brasileiras - como é o caso da sede metropolitana, que pela segunda vez apresenta saldo negativo nas trocas entre chegada e saída de migrantes. Essa perda ocorrida na capital decorre especialmente da relação com os municípios de seu entorno - fato que aponta para um processo de periferização de sua população. ${ }^{6}$ É interessante notar que, dentre os municípios envolvidos, encontram-se não somente aqueles que são tradicionalmente dormitórios, especialmente para trabalhadores em serviços mal remunerados na capital, como Viamão e Alvorada, mas também localidades com dinamismo industrial, como Gravataí e, de certo modo, Cachoeirinha. Canoas, segunda cidade da região em tamanho populacional, e que teve saldo positivo nas trocas entre emigração e imigração com Porto Alegre, apresentou saldo negativo no total das trocas, indicando que estão em curso processos de valorização imobiliária, que dificultam o acesso à moradia (Mapa 4). Essa conclusão ancora-se em estudo recente que constatou que essa localidade estava recebendo fluxos popu-

TABELA 2

Migrantes de Cinco Anos ou Mais (1), por Sub-Região de Residência Anterior Região Metropolitana de Porto Alegre - 2000

\begin{tabular}{|c|c|c|c|c|c|c|}
\hline \multirow{2}{*}{$\begin{array}{l}\text { Sub-Região de } \\
\text { Residência Atual }\end{array}$} & \multicolumn{6}{|c|}{ Sub-Região de Residência Anterior } \\
\hline & 1 & 2 & 3 & 4 & 5 & Total \\
\hline Total & 36.790 & 125.449 & 3.173 & 2.292 & 1.272 & 168.976 \\
\hline 1 & 25.635 & 11.518 & 220 & 512 & 338 & 38.223 \\
\hline 2 & 9.634 & 106.941 & 1.834 & 1.118 & 898 & 120.425 \\
\hline 3 & 432 & 3.991 & 878 & 202 & 36 & 5.539 \\
\hline 4 & 703 & 1.925 & 241 & 451 & - & 3.320 \\
\hline 5 & 386 & 1.074 & - & 9 & - & 1.469 \\
\hline
\end{tabular}

Fonte: IBGE. Censo Demográfico 2000; Microdados da amostra.

(1) Foram consideradas migrantes as pessoas de cinco anos ou mais que, na data da entrevista, residiam há menos de cinco anos no município. 
lacionais compostos por camadas médias e categorias sociais de renda mais alta (BARCELLOS, 2002). Alvorada e Viamão expandiram-se como continuidade das áreas periféricas de Porto Alegre. Embora algumas mudanças estejam se verificando nessas localidades - como a instalação de indústrias e o incremento da moradia de camadas médias - elas ainda se mantêm como "dormitório", característica que se confirma no estudo dos fluxos pendulares, como se verá mais adiante. Gravataí está passando por um momento de incremento significativo de seu dinamismo econômico, capitaneado pelo complexo automotivo da General Motors, que, justifica a atração de população.

A análise da migração com destino à RMPA, incluindo os fluxos originados em localidades que não integram a região, evidenciam que as forças centrípetas nela atuan- tes atingem um raio maior de extensão. Se nos fluxos intrametropolitanos foram verificados saldos positivos elevados - sobretudo no entorno de Porto Alegre -, quando é computada a totalidade da imigração/emigração, não somente amplia-se a atração nesse entorno imediato que envolve os municípios de Guaíba e Eldorado do Sul, como também passam a se destacar outros municípios. É o caso de São Leopoldo e de localidades pequenas da RMPA 1, que se encontram na área de influência dos municípiospólos do Vale dos Sinos, de Triunfo - município industrial que faz parte da sub-região 4 - e de Charqueadas localidade sem importância urbana, que integra a sub-região 3 , mas que, como visto antes, apresentou diferencial positivo nas trocas entre emigração e imigração com Porto Alegre (Mapa 5). Essas duas sub-regiões apresenta-

\section{MAPA 4}

Trocas Líquidas nos Fluxos Migratórios

Região Metropolitana de Porto Alegre - 1995/2000

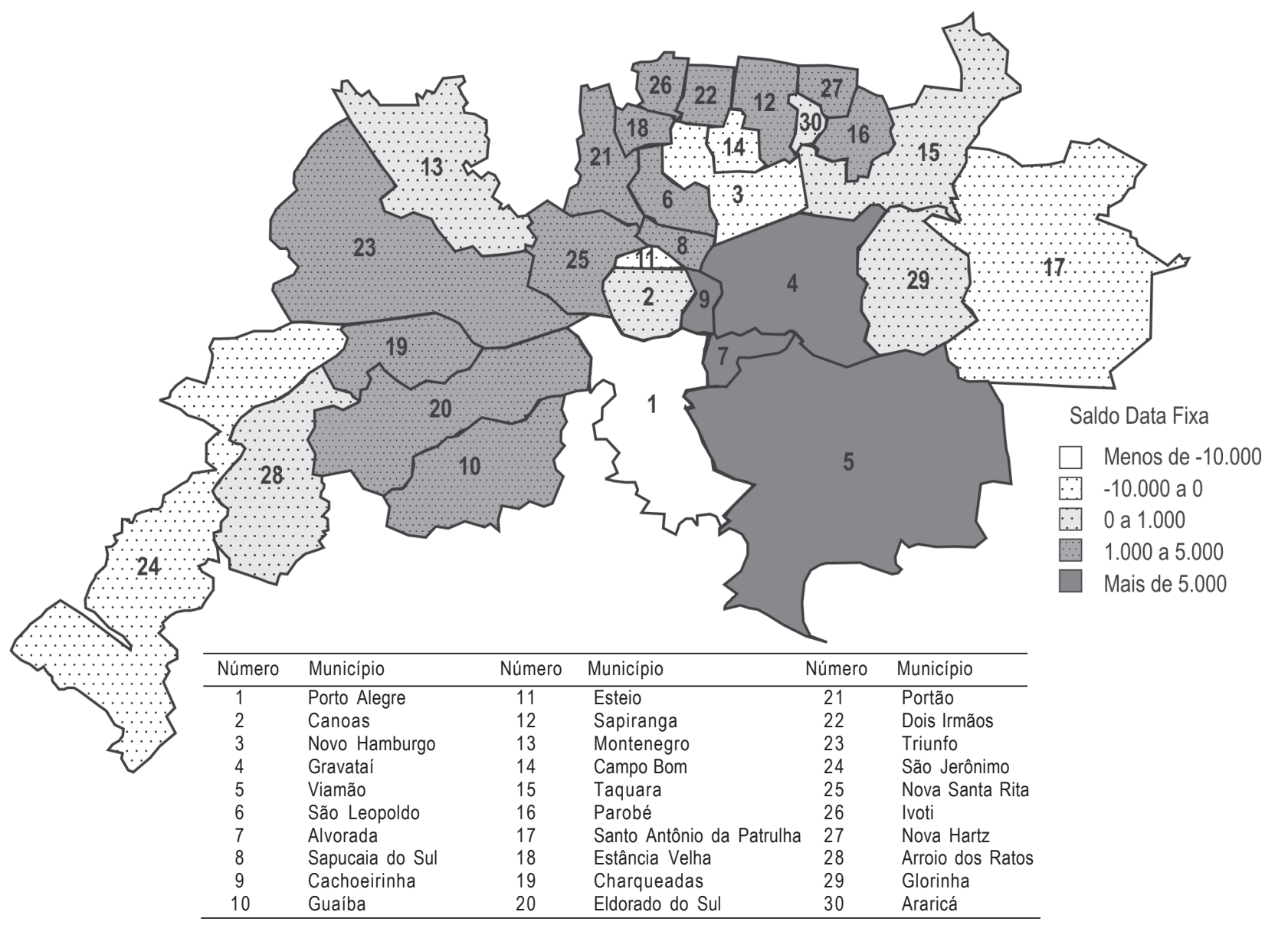

Fonte: IBGE. Censo Demográfico 2000; Microdados da Amostra. 
ram resultado positivo nas trocas entre saída e chegada de fluxos migratórios.

O perfil dos imigrantes na origem e no destino é uma informação fundamental para acrescentar conteúdo social à análise do fenômeno migratório metropolitano. Isso porque, como as mudanças das últimas décadas interferem na organização e localização da atividade econômica, também alteram a estrutura social e provocam rearticulações nas relações sociais. ${ }^{7}$

Para abordar essa problemática, utilizaram-se indicadores que analisam a distribuição por sexo, idade, faixas de renda e de instrução dos migrantes na RMPA.

Considerando o conjunto da população migrante e a população da RMPA como um todo, vê-se que, em linhas gerais, os perfis não são muito diferentes para os dois gru- pos, à exceção da estrutura etária, que aponta para uma configuração bastante carregada nas faixas de idade mais ativa ( 15 a 24 anos e 25 a 44 anos) entre os migrantes. Isso era evidentemente esperado e é compreensível, tendo em vista a correlação entre migração e mercado de trabalho o que explica, também, a existência de uma razão de sexo mais masculina no grupo dos migrantes.

Comparando os níveis de instrução e renda, encontrase uma relativa proximidade entre os dois grupos, com pequena vantagem para os migrantes na instrução (maior proporção nas faixas de 8 a 10 e de 11 a 14 anos de estudo), o que se reflete na média de anos de estudo dos migrantes, que é um pouco superior. Já em relação à renda, a população metropolitana em conjunto está melhor situada, com uma média mais alta e maior proporção nas faixas

MAPA 5

Trocas Líquidas nos Fluxos Migratórios Intrametropolitanos

Região Metropolitana de Porto Alegre - 1995/2000

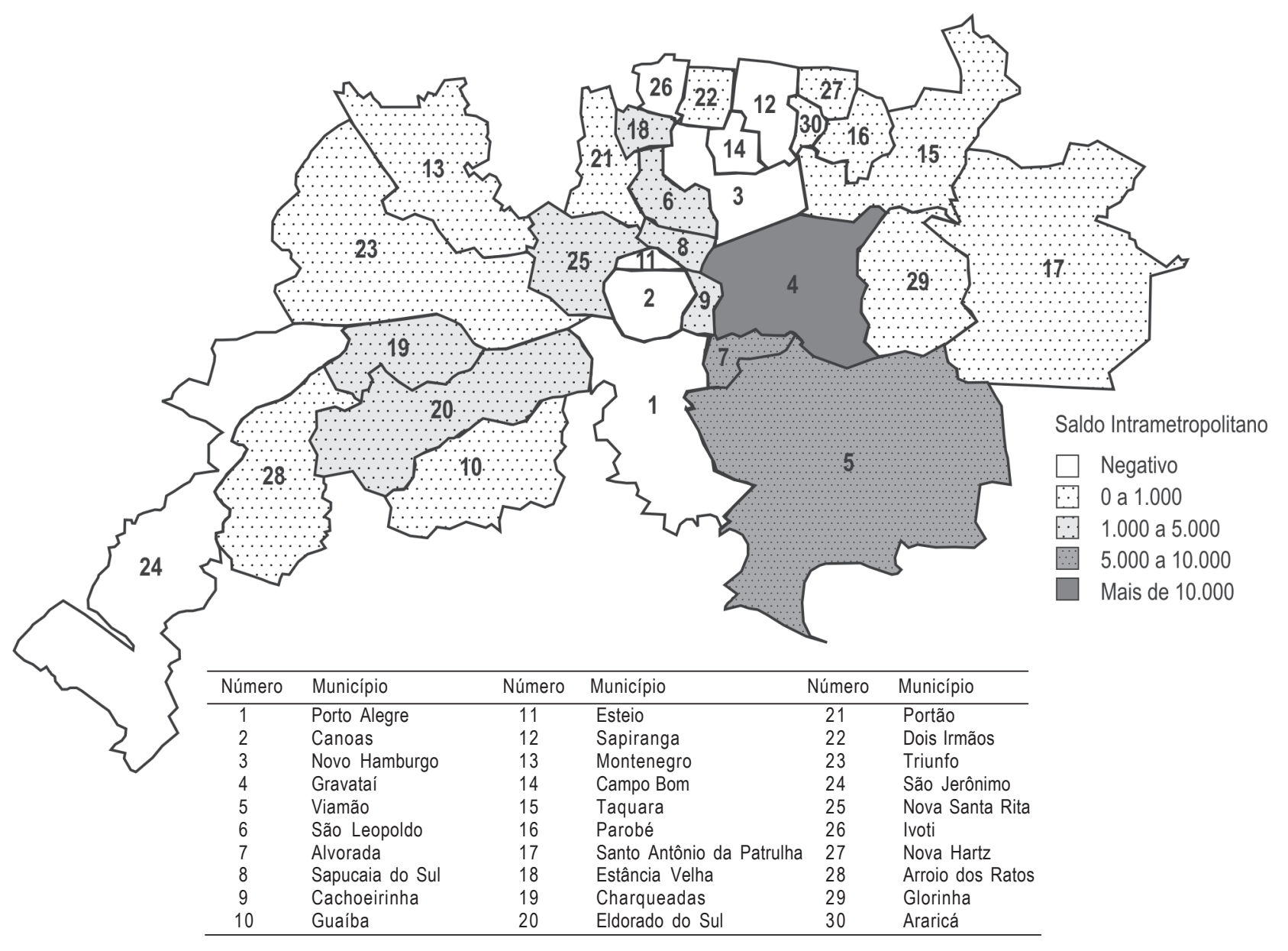

Fonte: IBGE. Censo Demográfico 2000; Microdados da Amostra. 
de 5 a 10, de 10 a 20 e mais de 20 salários mínimos (Tabela 3 ). Isso, de certo modo, indica que os problemas de inserção do migrante no mercado de trabalho são maiores, embora apresentem, em média, melhor qualificação.

Observando esses mesmos indicadores e considerando a origem e destino dos migrantes, constata-se que as pessoas que saíram da capital apresentam uma estrutura um pouco mais envelhecida, em especial se comparada com a dos que vieram do interior do Rio Grande do Sul. Os mi- grantes que saíram da capital, e, em especial, os que para ela se dirigiram, apresentam uma situação melhor em relação à instrução e à renda (Tabela 3 ). O fato de haver uma parcela da população com boas condições sociais que deixa Porto Alegre para viver em municípios que constituem uma extensão de seus bairros periféricos é um indicativo de mudança no conteúdo dos deslocamentos da capital para municípios de seu entorno, que eram majoritariamente de exclusão de camadas muito pobres do

TABELA 3

População Total e Migrantes de Cinco Anos ou Mais (1), por Local de Residência Anterior, segundo Variáveis Pessoais Região Metropolitana de Porto Alegre - 2000

\begin{tabular}{|c|c|c|c|c|c|c|c|}
\hline \multirow{3}{*}{ Variáveis Pessoais } & \multirow{3}{*}{$\begin{array}{l}\text { População } \\
\text { Total }\end{array}$} & \multicolumn{5}{|c|}{ Migrantes } & \multirow[b]{3}{*}{ Total } \\
\hline & & \multicolumn{3}{|c|}{ RMPA } & \multirow{2}{*}{$\begin{array}{c}\text { RS } \\
\text { exceto } \\
\text { RMPA }\end{array}$} & \multirow[b]{2}{*}{ Outros } & \\
\hline & & Porto Alegre & $\begin{array}{c}\text { Exceto } \\
\text { Porto Alegre }\end{array}$ & Total & & & \\
\hline Sexo & 3.708 .746 & 60.512 & 108.458 & 168.970 & 131.141 & 51.237 & 351.348 \\
\hline Mulheres & 1.916 .289 & 29.902 & 53.517 & 83.419 & 63.861 & 25.845 & 173.125 \\
\hline Homens & 1.792 .457 & 30.610 & 54.941 & 85.551 & 67.280 & 25.392 & 178.223 \\
\hline Idade & 3.708 .745 & 60.511 & 108.459 & 168.970 & 131.140 & 51.236 & 351.346 \\
\hline De 0 até 9 Anos & 645.903 & 5.977 & 11.785 & 17.762 & 11.482 & 4.996 & 34.240 \\
\hline De 10 até 14 Anos & 325.505 & 5.564 & 9.834 & 15.398 & 10.825 & 4.573 & 30.796 \\
\hline De 15 até 24 Anos & 687.154 & 11.191 & 24.566 & 35.757 & 41.610 & 13.119 & 90.486 \\
\hline De 25 até 44 Anos & 1.154 .467 & 25.836 & 44.607 & 70.443 & 49.087 & 21.126 & 140.656 \\
\hline De 45 até 64 Anos & 660.650 & 9.481 & 14.089 & 23.570 & 13.768 & 6.008 & 43.346 \\
\hline 65 Anos ou Mais & 235.066 & 2.462 & 3.578 & 6.040 & 4.368 & 1.414 & 11.822 \\
\hline $\begin{array}{l}\text { Renda (em salários } \\
\text { mínimos) }\end{array}$ & 3.061 .435 & 54.473 & 96.624 & 151.097 & 119.583 & 46.229 & 316.909 \\
\hline Até $1 / 2 \mathrm{SM}$ & 38.157 & 649 & 1.772 & 2.421 & 1.727 & 594 & 4.742 \\
\hline Mais de $1 / 2$ a $1 \mathrm{SM}$ & 273.294 & 4.236 & 8.285 & 12.521 & 10.901 & 2.999 & 26.421 \\
\hline Mais de 1 a $2 \mathrm{SM}$ & 510.348 & 7.938 & 17.401 & 25.339 & 27.148 & 8.243 & 60.730 \\
\hline Mais de 2 a $5 \mathrm{SM}$ & 645.430 & 12.450 & 21.379 & 33.829 & 26.207 & 7.902 & 67.938 \\
\hline Mais de 5 a $10 \mathrm{SM}$ & 323.964 & 6.509 & 9.516 & 16.025 & 9.141 & 5.225 & 30.391 \\
\hline Mais de 10 até $20 \mathrm{SM}$ & 149.830 & 2.414 & 3.227 & 5.641 & 4.360 & 3.236 & 13.237 \\
\hline Mais de $20 \mathrm{SM}$ & 84.960 & 1.298 & 1.337 & 2.635 & 2.107 & 2.222 & 6.964 \\
\hline Sem Renda & 1.035 .452 & 18.979 & 33.707 & 52.686 & 37.992 & 15.808 & 106.486 \\
\hline Anos de Estudo & 3.686 .390 & 60.118 & 107.742 & 167.860 & 130.297 & 50.878 & 349.035 \\
\hline De 1 a 3 e Alfab. Adulto & 488.256 & 7.374 & 16.794 & 24.168 & 16.333 & 5.967 & 46.468 \\
\hline De 4 a 7 Anos & 1.142 .031 & 19.119 & 39.241 & 58.360 & 46.202 & 13.799 & 118.361 \\
\hline De 8 a 10 Anos & 580.099 & 11.794 & 18.933 & 30.727 & 23.399 & 8.749 & 62.875 \\
\hline De 11 a 14 Anos & 609.387 & 13.068 & 18.141 & 31.209 & 24.791 & 12.811 & 68.811 \\
\hline 15 Anos e Mais & 216.541 & 3.226 & 3.530 & 6.756 & 8.006 & 5.584 & 20.346 \\
\hline Sem Instrução & 650.076 & 5.537 & 11.103 & 16.640 & 11.566 & 3.968 & 32.174 \\
\hline
\end{tabular}

Fonte: IBGE. Censo Demográfico 2000; Microdados da amostra.

(1) Foram consideradas migrantes as pessoas com cinco anos ou mais que, na data da entrevista, residiam há menos de cinco anos no município. 
acesso à moradia, em função da valorização fundiária. Nessa constatação, pode-se identificar um novo processo, no qual são protagonistas as camadas de renda média e alta que, mais recentemente, optam pela moradia em condomínios fechados, também nas localidades próximas do centro metropolitano (LAGO, 2000; MATOS; LOBO; STEFANI, 2003).

Quando os municípios são estratificados por sub-região e o perfil sociodemográfico é examinado, podem ser obtidos alguns resultados que permitem avançar um pouco mais na abordagem das especificidades sociais dos espaços da metrópole, as quais são configuradas e expressas nas trocas populacionais. ${ }^{8}$

Primeiramente, constata-se que existem algumas especificidades na análise da composição social dos diferentes grupos. Somente na variável "idade" não se encontram diferenciais significativos: a concentração nas faixas mais ativas se mantém, em especial no intervalo dos 25 aos 44 anos, que caracteriza a estrutura dos migrantes em geral. As particularidades evidenciam-se em relação à instrução e à renda. É o caso dos migrantes cujo destino foi a RMPA 2, polarizada por Porto Alegre, que se destaca com níveis bastante mais elevados de instrução e com a menor incidência nas faixas mais baixas de renda. Mesmo sem apresentar o maior percentual nos intervalos mais elevados, essa sub-região distingue-se por uma distribuição mais equilibrada. A sub-região 1 tem um perfil semelhante, embora um pouco mais "pobre". As demais mostram perfis bem menos qualificados e mais empobrecidos. Isso reflete as maiores oportunidades existentes nas áreas onde se concentram as atividades e o dinamismo econômico é maior. ${ }^{9}$

\section{A MOBILIDADE PENDULAR}

Os dados levantados pelo Censo Demográfico 2000 sobre o "deslocamento da população do município de residência para trabalhar ou estudar em outro município" - a chamada "mobilidade pendular" - mostram que existe um fluxo considerável de pessoas que diariamente se deslocam para outro município, onde trabalham ou estudam, utilizando, portanto, muito mais a infra-estrutura deste do que a daquele de residência.

No Brasil, 7,4 milhões de pessoas trabalham ou estudam fora do município de residência - o que representa $6,7 \%$ das pessoas que trabalham ou estudam. No Rio Grande do Sul, essa proporção é de 8,0\% (JARDIM, 2003). Quando são consideradas as regiões metropolitanas brasileiras, esse porcentual sobe para 10,6\%. Na RMPA, esse fenô- meno é ainda mais significativo, pois o porcentual de pessoas que se deslocam para trabalhar ou estudar é de 14,8\%. Esse porcentual é bastante representativo, mesmo sendo uma característica das regiões metropolitanas, em função da grande ligação entre os seus municípios - o que envolve um movimento constante de pessoas. ${ }^{10}$

Embora a informação levantada pelo Censo não separe os fluxos entre trabalho ou estudo, considera-se que a maior parte deles seja para trabalhar. Isso significa que uma parcela relevante da população passa a maior parte do horário comercial fora do município. De fato, examinando a condição de ocupação das pessoas em mobilidade, ${ }^{11}$ observa-se que o porcentual de pessoas que só trabalham é muito elevado, principalmente entre os que moram na periferia da RMPA e trabalham em Porto Alegre. ${ }^{12}$

Quando são comparados os perfis da população que trabalha ou estuda no próprio município e da que se desloca para outro município (Tabela 4), podemos detectar diferenciais interessantes em algumas características. Os dados mostram que a população que trabalha ou estuda em outro município é mais masculina, mais velha e, apesar de ter menor instrução, possui uma renda média mais elevada. Quando se comparam os perfis da população que se desloca do município de residência para Porto Alegre e os da que se desloca para os outros municípios da RMPA verifica-se que a população que tem como destino a capital tem traços distintos. Ela é menos masculina do que a que sai para a periferia da Região Metropolitana e, apesar de a idade média ser mais elevada, possui menor escolaridade e menor rendimento médio. Tais características são condizentes com a absorção de mão-de-obra em serviços predominante na capital, ficando as atividades industriais concentradas nos municípios periféricos.

A dinâmica da mobilidade pendular da Região Metropolitana de Porto Alegre pode ser sintetizada por meio da distribuição geográfica dos fluxos, considerando-se os volumes no município de origem (o local de residência), os volumes no município de destino (o local onde trabalha ou estuda) e os saldos (ganhos populacionais do município pelos movimentos pendulares).

A partir da análise dessas informações, pode-se ver que os municípios com volume significativo de população que se desloca para trabalhar ou estudar formam uma área contígua. Já naqueles mais distantes do núcleo, os volumes dos que saem são mais baixos. ${ }^{13} \mathrm{O}$ destino desses movimentos pendulares, por sua vez, está concentrado tanto no município de Porto Alegre - que reúne grande parte do comércio e de serviços mais especializados - e nos de Ca- 
TABELA 4

População Residente Total e População que se Desloca do Município de Residência para Trabalhar ou Estudar, por Lugar de Trabalho ou Estudo, segundo Variáveis Pessoais Região Metropolitana de Porto Alegre - 2000

\begin{tabular}{|c|c|c|c|c|c|c|c|c|}
\hline \multirow{4}{*}{$\begin{array}{l}\text { Variáveis } \\
\text { Pessoais }\end{array}$} & \multicolumn{6}{|c|}{ Local de Deslocamento para Trabalho ou Estudo } & \multirow{4}{*}{$\begin{array}{c}\text { Trabalha ou } \\
\text { Estuda no } \\
\text { Próprio Município }\end{array}$} & \multirow{4}{*}{$\begin{array}{l}\text { Total } \\
\text { Geral }\end{array}$} \\
\hline & \multirow{3}{*}{ Porto Alegre } & \multicolumn{2}{|l|}{ RMPA } & \multirow{3}{*}{$\begin{array}{c}\text { RS } \\
\text { exceto } \\
\text { RMPA }\end{array}$} & \multirow{3}{*}{ Outros } & \multirow{3}{*}{ Total } & & \\
\hline & & Exceto & Total & & & & & \\
\hline & & Porto Alegre & & & & & & \\
\hline Razão de Sexo & 140,4 & 179,4 & 155,0 & 199,4 & 123,1 & 154,7 & 117,4 & 122,2 \\
\hline Idade Média & 34,7 & 32,5 & 33,8 & 34,2 & 28,0 & 33,6 & 27,3 & 28,2 \\
\hline $\begin{array}{l}\text { Renda Média(em salários } \\
\text { mínimos) }\end{array}$ & 4,1 & 5,1 & 4,5 & 6,1 & 5,0 & 4,6 & 3,8 & 3,9 \\
\hline Média de Anos de Estudo & 5,4 & 6,3 & 5,8 & 6,0 & 8,7 & 5,9 & 6,0 & 6,0 \\
\hline
\end{tabular}

Fonte: IBGE. Censo Demográfico 2000; Microdados da amostra.

noas e Novo Hamburgo, ${ }^{14}$ que são centros industriais relevantes na região.

Quando se avaliam os saldos da mobilidade pendular, as diferenças são ainda mais contrastantes. Somente Porto Alegre e Novo Hamburgo possuem saldos dos fluxos pendulares superiores a 10 mil habitantes, sendo que a distância entre o resultado da capital - 188 mil pessoas -, e o de Novo Hamburgo - 10 mil - é abismal. Também é digno de nota o saldo de Triunfo - 4 mil - que foi o terceiro maior em volume. Apesar de ser menos da metade do alcançado por Novo Hamburgo, está muito acima dos outros três municípios do grupo dos que possuem saldos positivos menores que 10 mil, que são: Nova Hartz, com 109 habitantes; São Jerônimo, com 36 habitantes, e Ivoti, com 28 habitantes (Mapa 6). Com relação a Triunfo, devese destacar a presença do Pólo Petroquímico, que utiliza trabalhadores residentes em outros municípios.

Quando se consideram os vínculos inter-regionais que podem ser representados pela mobilidade pendular, segundo as sub-regiões da RMPA, evidenciam-se os pólos de atração e a sua relação com os municípios da sub-região. Muito embora grande parte dos municípios que as integram tenham apresentado saldos negativos no cômputo entre quanto recebem de fluxos para trabalho ou estudo e quanto liberam de fluxos pendulares, a capacidade de atração de Porto Alegre, no caso da RMPA 2, e de Novo Hamburgo, na RMPA 1, acabou por gerar um saldo positivo não desprezível em nível desses espaços sub-regionais. Também os fluxos recebidos por Triunfo, que é o município mais importante da RMPA 4, compensaram as saídas de população da sub-região para trabalhar ou estudar fora. Somente as sub-regiões 3 e 5 - que na verdade são caudatárias de outros centros urbanos mais importantes - tiveram saldos negativos nessas trocas (Tabela 5).

Quando são analisados os saldos sub-regionais considerando-se apenas os fluxos intrametropolitanos, observa-se que os resultados da RMPA 2 refletem, na verdade, a mobilidade pendular de fora da região metropolitana - já que, sem esses números, seu saldo é negativo. Vê-se portanto que, mesmo com o saldo positivo muito elevado de Porto Alegre, as diferenças negativas de outras localidades como Alvorada e Viamão - onde é muito grande a saída de pessoas para trabalhar ou estudar na capital $-{ }^{15}$ tornam a RMPA 2 deficitária nos fluxos intrametropolitanos.

Em grande parte, esses movimentos entre Porto Alegre e seu entorno ficam mais claros quando se examina a distribuição da população que trabalha ou estuda na capital, segundo o local de residência em 1995 (Tabela 6). Ela mostra que mais da metade das pessoas que trabalham ou estudam em Porto Alegre eram residentes em 1995, revelando, portanto, que apesar de emigrarem da capital, continuam mantendo vínculo com aquele município. Assim, fica comprovado que, para uma grande parte das pessoas, a procura por trabalho ou estudo não foi a motivação para a mudança de local de moradia. ${ }^{16}$

Outro indicador importante para a análise dos movimentos pendulares é o porcentual de acréscimo populacional que eles geram em relação à população que trabalha ou estuda. Esse indicador mede o plus populacional, que deve ser considerado na formulação de políticas públicas de atendimento dessa parcela da população no município de trabalho ou estudo e, em contrapartida, na formulação de políticas de geração de emprego no município de origem - já que a grande maioria se desloca para trabalhar. 


\section{MAPA 6}

Trocas Líquidas nos Fluxos Pendulares

Região Metropolitana de Porto Alegre - 1995/2000

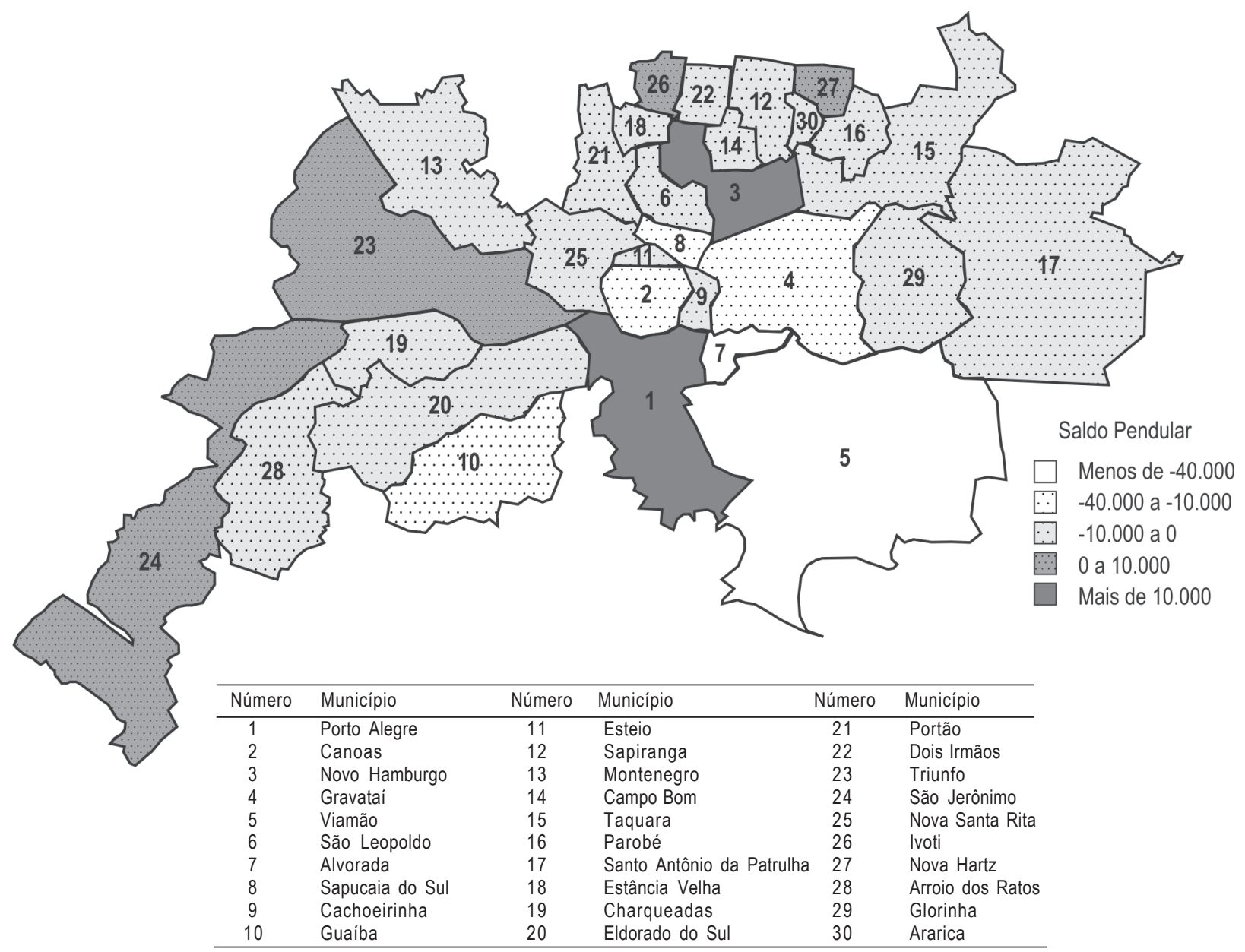

Fonte: IBGE. Censo Demográfico 2000; Microdados da Amostra.

TABELA 5

Mobilidade Pendular, segundo Sub-Região

Região Metropolitana de Porto Alegre - 2000

\begin{tabular}{|c|c|c|c|c|c|c|}
\hline \multirow[b]{2}{*}{ Sub-Região } & \multicolumn{3}{|c|}{ Total } & \multicolumn{3}{|c|}{ Intrametropolitana } \\
\hline & $\begin{array}{l}\text { Lugar de } \\
\text { Trabalho ou Estudo }\end{array}$ & $\begin{array}{l}\text { Lugar de } \\
\text { Residência }\end{array}$ & Saldo & $\begin{array}{l}\text { Lugar de } \\
\text { Trabalho ou Estudo }\end{array}$ & $\begin{array}{l}\text { Lugar de } \\
\text { Residência }\end{array}$ & Saldo \\
\hline RMPA 1 & 63.113 & 58.473 & 4.640 & 55.373 & 53.396 & 1.977 \\
\hline RMPA 2 & 291.372 & 276.462 & 14.910 & 269.842 & 271.779 & -1.937 \\
\hline RMPA 3 & 2.505 & 4.086 & -1.581 & 1.858 & 3.713 & -1.855 \\
\hline RMPA 4 & 6.516 & 3.367 & 3.149 & 5.152 & 2.696 & 2.456 \\
\hline RMPA 5 & 407 & 1.749 & -1.342 & 222 & 863 & -641 \\
\hline
\end{tabular}

Fonte: IBGE. Censo Demográfico 2000; Microdados da amostra. 
TABELA 6

População que se Desloca do Município de Residência para Trabalhar ou Estudar Região Metropolitana de Porto Alegre - 2000

\begin{tabular}{lcccccc}
\hline $\begin{array}{l}\text { Município de } \\
\text { Residência }\end{array}$ & $\begin{array}{c}\text { Porto } \\
\text { Alegre }\end{array}$ & $\begin{array}{c}\text { RMPA exceto } \\
\text { Porto Alegre }\end{array}$ & $\begin{array}{c}\text { RS exceto } \\
\text { RMPA }\end{array}$ & Outros & Total & $\begin{array}{c}\text { Participação de } \\
\text { Porto Alegre (\%) }\end{array}$ \\
\hline Total & 18.780 & 8.253 & 7.652 & 2.343 & 37.028 & 50,7 \\
RMPA & 17.721 & 7.847 & 6.959 & 2.180 & 34.706 & 51,1 \\
Viamão & 4.648 & 891 & 1.379 & 486 & 7.403 & 62,8 \\
Alvorada & 3.864 & 1.041 & 1.404 & 335 & 6.644 & 58,2 \\
Gravataí & 2.325 & 1.594 & 756 & 333 & 5.008 & 46,4 \\
Cachoeirinha & 2.159 & 883 & 585 & 226 & 3.853 & 56,0 \\
Canoas & 1.789 & 839 & 1.178 & 347 & 4.151 & 43,1 \\
Guaíba & 925 & 377 & 305 & 58 & 1.665 & 55,5 \\
Eldorado do Sul & 549 & 279 & 324 & 101 & 1.254 & 43,8 \\
Outros Municípios & & & & & & 4.728 \\
da RMPA & 1.462 & 1.944 & 1.028 & 294 & 2.322 & 30,9 \\
RS Fora da RMPA & 1.059 & 407 & 693 & 163 & & 45,6 \\
\hline
\end{tabular}

Fonte: IBGE. Censo Demográfico 2000; Microdados da amostra.

MAPA 7

Acréscimo Populacional devido aos Movimentos Pendulares, em Relação ao Total da População que Trabalha ou Estuda Região Metropolitana de Porto Alegre - 2000

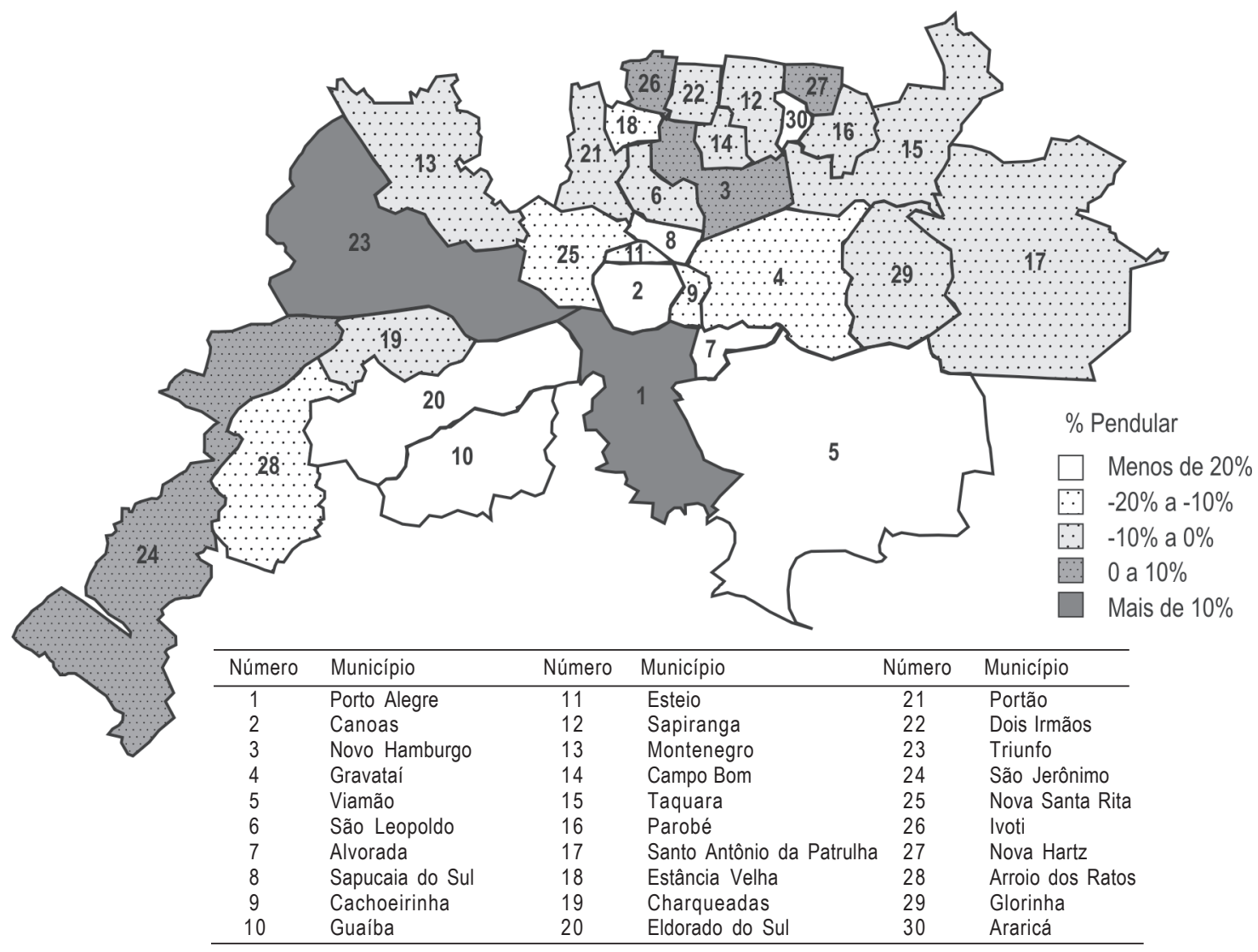

Fonte: IBGE. Censo Demográfico 2000; Microdados da Amostra. 
Na RMPA, os municípios que têm um acréscimo de mais de $10 \%$ na sua população, em função dos deslocamentos pendulares, são: Triunfo (28,9\%) e Porto Alegre (20,6\%). O plus migratório pendular de Novo Hamburgo representa o terceiro maior, com $6,6 \%$ de acréscimo em sua população. As maiores perdas relativas de população são as dos municípios de Alvorada (-38,7\%), Viamão (-33,1\%), Araricá17 (-22,8\%), Sapucaia do Sul (-22,3\%), Eldorado do Sul (-21,6\%), e Guaíba (-20,7\%). Note-se que, à exceção de Araricá, são todos municípios do entorno de Porto Alegre (Mapa 7) que não apresentam grande dinamismo econômico.

\section{CONSIDERAÇÕES FINAIS}

Refletindo sobre os resultados da análise da mobilidade populacional na RMPA durante os anos 90, na sua relação com as mudanças econômicas que a região experimentou, alguns pontos que dizem respeito à dinâmica desse espaço, em várias dimensões, devem ser ressaltados:

- seguindo a tendência encontrada em outras metrópoles nacionais, o aumento da importância dos deslocamentos intrametropolitanos frente aos fluxos provenientes do interior do Estado significa que, como pólo privilegiado de crescimento populacional e econômico, a RMPA recebe os efeitos da reestruturação econômica e da crise que esse processo tem engendrado - cujos impactos se fazem sentir na redução em geral dos movimentos migratórios e no aprofundamento dos vínculos sociais e econômicos entre as localidades que integram a metrópole;

- a sub-região polarizada por Porto Alegre - com concentração não só de indústrias, mas especialmente do comércio e dos serviços - constitui o espaço que apresenta as maiores condições de atratividade na RMPA, que se reforçaram nos anos 90 com o processo de reconcentração da atividade industrial;

- ao mesmo tempo, nesse período, persiste uma tendência de ampliação do peso da migração para a RMPA 1 - o que indica que os fatores atrativos naquela área crescem, provavelmente, como resposta à dinâmica da indústria coureiro-calçadista que é grandemente absorvedora de mão-de-obra;

- na análise das trocas líquidas entre imigração e emigração nos municípios da RMPA, mais uma vez se destaca o saldo negativo da sede metropolitana, que perde nas relações com os municípios de seu entorno - fato que aponta para um processo de expulsão da sua população. Novo é o fato de que os municípios envolvidos não se restringem aos tradicionais dormitórios, como Viamão e Alvorada, mas abrangem também localidades com dinamismo industrial como Gravataí e, de certo modo, Cachoeirinha;

- na metrópole gaúcha, o perfil identificado nos migrantes explicita uma realidade ainda adversa para esse grupo no mercado de trabalho, pois, embora com qualificação um pouco melhor, têm rendimento médio mais baixo, já os que saíram da capital - e, em especial os que para ela se dirigiram apresentam melhores condições em relação à instrução e à renda. No que se refere aos que saíram de Porto Alegre, a mobilidade para localidades de seu entorno tem outros componentes além do já conhecido conteúdo de exclusão e segregação de camadas muito pobres. É possível que nesse fato se manifeste a escolha crescente das camadas de renda média e alta pela moradia em condomínios fechados, nas localidades próximas do centro metropolitano;

- em termos de diferenças sociais no interior do espaço metropolitano, pode-se salientar que há melhor condição na estrutura de renda e instrução dos migrantes da RMPA 2, polarizada por Porto Alegre, e, de certo modo, dos que tiveram por destino a RMPA 1 , embora nela o perfil seja um pouco mais "pobre". As demais mostram perfis bem menos qualificados e mais empobrecidos, que refletem as maiores oportunidades existentes nas áreas onde se concentram as atividades e o dinamismo econômico é maior; - na mobilidade pendular, outras relações se evidenciam. De um lado, o movimento moradia-trabalho mostra a dependência de áreas menos dinâmicas em relação ao centro metropolitano, quando revela que a população que se desloca para Porto Alegre, apesar de ter a idade média mais elevada, possui menor escolaridade e menor rendimento médio. De outro, a melhor situação dos que se dirigiram para outras localidades da região indica as alternativas fora da capital propiciadas pela concentração da produção industrial em outros municípios;

- a análise da mobilidade pendular aponta, ainda, para a importância do dinamismo econômico na configuração dos deslocamentos, ao mostrar que o destino desses fluxos está concentrado nos municípios de Porto Alegre, Canoas e Novo Hamburgo;

- por fim, ao examinar os dados, o fato de cruzar a mobilidade pendular com a migração de data fixa torna mais claros os conteúdos dos movimentos entre Porto Alegre e seu entorno. Constatou-se que mais da metade das pessoas que trabalhavam ou estudavam em Porto Alegre em 2000 moravam na capital em 1995, revelando que os vínculos com a cidade se mantêm, apesar da migração - o que comprova que, para uma grande parte das pessoas, a motivação para a mudança de local de moradia não foi a procura por trabalho ou estudo. 


\section{NOTAS}

Trabalho apresentado no XIV Encontro Nacional de Estudos Populacionais - Abep, realizado em Caxambu - MG - Brasil, de 20 a 24 de setembro de 2004. O estudo foi elaborado no contexto do projeto de pesquisa Desigualdades Socioespaciais na RMPA, integrado ao Núcleo de Estudos Regionais e Urbanos da FEE. O projeto recebeu recursos do Programa Pró-Guaíba e da Fapergs e, em termos institucionais, estava integrado ao Projeto "Metrópole, Desigualdades Socioespaciais e Governança Urbana: Rio de Janeiro, São Paulo, Belo Horizonte e Porto Alegre", coordenado pelo IPPUR/ UFRJ, inserido no Programa de Apoio a Núcleos de Excelência (Pronex). As autoras incorporaram as interessantes sugestões do parecerista, que acrescentaram clareza e qualidade ao texto.

1. A abordagem da economia baseou-se em estudo sobre a dinâmica recente da economia metropolitana (ALONSO, 2003), e nas pesquisas sobre o mercado de trabalho, realizadas pela FEE/PED.

2. Santo Amaro é atualmente o município de General Câmara.

3. É importante esclarecer que essa regionalização, como em geral são tais construções, é provisória e encontra-se em discussão. Ela procura demarcações relacionadas com a estrutura e a dinâmica da economia metropolitana, que está passando por um momento de profundas transformações.

4. Esse complexo inclui as divisões: Produtos Alimentícios e Bebidas, Produtos do Fumo, Preparação de Couros e Fabricação de Artefatos de Couro, Artigos de Viagem e Calçados, Produtos Têxteis, Confecção de Artigos do Vestuário e Acessórios.

5. Utilizou-se a variável 3211 do Censo Demográfico 1991 e a variável 4250 do Censo de 2000, ambas dando conta da origem do migrante em uma data fixa (cinco anos antes do levantamento censitário).

6. Sobre o processo de periferização da população de centros metropolitanos, ver livro organizado por Maricato (1982) e, mais recentemente, o trabalho de Matos (2003), sobre Belo Horizonte.

7. Muitos estudos apontam tendências de polarização social nas grandes metrópoles, com auto-segregação das elites, camadas populares "enguetadas" e alterações no tamanho, papel e estilo de vida das camadas médias (RIBEIRO, 2000; LAGO, 2000).

8. As informações sobre o perfil dos migrantes nas sub-regiões foram obtidas a partir dos microdados do Censo Demográfico 2000.

9. A sub-região 5 - que, como já se mencionou antes, é composta pelo município de Santo Antônio, incorporado à região em 2000 apresenta movimentos populacionais muito reduzidos, o que se soma à sua pequena importância na dinâmica econômica da RMPA. A RMPA 3, que reúne São Jerônimo, Arroio dos Ratos e Charqueadas, tem também características urbanas pouco expressivas. À exceção de Charqueadas, que apresentou saldo positivo significativo nas trocas dos fluxos intrametropolitanos, os demais municípios parecem não manter vínculos muito importantes com a região. Na verdade, uma parte considerável desses fluxos tem origem e destino exteriores à região, o que leva a pensar que sua integração não responde aos critérios propostos pelo órgão metropolitano para avaliar os processos de incorporação de novos municípios à área. Esses critérios dizem respeito a aspectos funcionais (vínculos existentes entre a cidade-núcleo da região e o município postulante, medidos pelos deslocamentos moradia-trabalho ou, genericamente, pelos fluxos de pessoas, bens e comunicação); demográficos (características do crescimento populacional comparadas com o comportamento da região e do Estado, examinando-se, principalmente, componentes de crescimento populacional); econômicos (complementaridade de atividades econômicas entre o município em análise e outros da região, ou o compartilhamento do mercado de trabalho urbano por parte de moradores de vários municípios); físico-territoriais (existência ou tendência significativa de continuidade da urbanização entre o mu- nicípio em análise e o pólo regional, direta ou indiretamente, através de outros municípios); institucionais (referidos à posição do município em outras regionalizações existentes no Estado e ao processo de planejamento metropolitano); e, finalmente, critérios ambientais (desenvolvimento sustentável regional) (METROPLAN, 1999).

10. Somente nas Regiões Metropolitanas de Grande Vitória (com $17,8 \%)$ e Florianópolis $(15,8 \%)$ os porcentuais são maiores do que na Região Metropolitana de Porto Alegre.

11. Informação obtida através do cruzamento de variáveis de instrução e trabalho.

12. As pessoas residentes em Porto Alegre distribuem-se em relação à condição de ocupação na seguinte proporção: $5,7 \%$ só estudam; $83,2 \%$ só trabalham; e $11,2 \%$ estudam e trabalham (conforme microdados da amostra do Censo Demográfico 2000).

13. Os municípios maiores também concentram os maiores volumes de migração pendular.

14. As cifras dos municípios de Canoas e Novo Hamburgo são bastante distintas das de Porto Alegre: enquanto esta recebe mais de 200 mil migrantes pendulares, o volume de imigração pendular para Canoas e Novo Hamburgo não chega a $30 \mathrm{mil}$.

15. O porcentual de pessoas que saem de Alvorada e Viamão para trabalhar ou estudar em Porto Alegre e que em 1995 residiam em Porto Alegre é de $62,8 \%$ e de $58,2 \%$, respectivamente.

16. Matos, Lima e Braga (2003) também chegaram a esses resultados, quando estudaram o caso de Belo Horizonte.

17. Cuja população total é de menos de 5.000 habitantes.

\section{REFERÊNCIAS BIBLIOGRÁFICAS}

ALONSO, J.A.F. Efeitos da reestruturação produtiva na estrutura sócio-ocupacional das regiões metropolitanas de Porto Alegre e Curitiba nos anos 90: um estudo comparativo. In: ENCONTRO METRÓPOLES: desigualdades e governança urbana. Curitiba, Ipardes, 6 e 7 nov. 2003.

BAENINGER, R. Regionalização e migração em São Paulo: características dos anos 80. In: ENCONTRO NACIONAL DA ANPUR, 7., Anais... Recife, 26 a 30 maio 1997.

BARCELLOS, T.M. de. Deslocamentos populacionais na Região Metropolitana de Porto Alegre: características dos anos 80. In: ENCONTRO NACIONAL DE ESTUDOS POPULACIONAIS, 2002, Ouro Preto. Violências, o Estado e a qualidade de vida da população brasileira, 2002 .

BARCELLOS, T.M. de. Um olhar exploratório sobre a dinâmica imobiliária na RMPA nos anos 90. In: ENCONTRO ANUAL DA ANPOCS, 27., Anais... Caxambu, 21 a 25 out. 2003.

CARRION, O.B.K. Mercado imobiliário e padrão periférico de moradia: Porto Alegre e sua Região Metropolitana. Ensaios $F E E$, Porto Alegre, v. 10, n. 2, p. 225-250, 1989.

CASTELLO BRANCO, M.L.G. Espaços urbanos e a produção de informações. In: ENCONTRO ANUAL DA ANPOCS, 27., Anais... Caxambu, 21 a 25 out. 2003.

FEE - Fundação de Economia e Estatística. Informe PED, Porto Alegre, ano 12, n. 12, dez. 2003.

HARVEY, D. A condição pós-moderna. São Paulo: Loyola, 1992. 
JARDIM, M. de L.T. A migração pendular na Região Metropolitana de Porto Alegre. Carta de conjuntura, Porto Alegre, FEE, ano 12 , n. 2, fev. 2003.

LAGO, L.C. do. O que há de novo na clássica dualidade núcleoperiferia: a metrópole do Rio de Janeiro. In: RIBEIRO, L.C. de Q. (Org.). O futuro das metrópoles: desigualdades e governabilidade. Rio de Janeiro: Revan, Fase, 2000. p. 207-228.

MARICATO, E. (Org.). A produção capitalista da casa (e da cidade) no Brasil industrial. São Paulo: Alfa-Omega, 1982.

MATOS, R.; LIMA, C.F.; BRAGA, F.G. Dispersão demográfica nas periferias da Região Metropolitana de Belo Horizonte. In: ENCONTRO TRANSDISCIPLINAR SOBRE ESPAÇO E

POPULAÇÃO, 1., Campinas, Unicamp, 13 a 15 nov. 2003.

MATOS, R.; LOBO, C.; STEFANI, J. Pobreza urbana e a dimensão socioespacial nos processos de redistribuição da população em periferias de Belo Horizonte. In: ENCONTRO TRANSDISCIPLINAR SOBRE ESPAÇO E POPULAÇÃO, 1., Campinas, Unicamp, 13 a 15 nov. 2003.

METROPLAN. Considerações sobre conceitos e delimitação da Região Metropolitana de Porto Alegre. Porto Alegre: 1999.

ORTH, C.A.; ALVES, T.W. O processo de ocupação do espaço urbano em Porto Alegre. Perspectiva Econômica, São Leopoldo, Unisinos, v. 36, n. 114, p. 89-127, abr./jun. 2001.
RIBEIRO, L.C. de Q. Cidade desigual ou cidade partida? Tendências da metrópole do Rio de Janeiro. In: (Org.).

O futuro das metrópoles: desigualdades e governabilidade. Rio de Janeiro: Revan, Fase, 2000. p. 62-98.

SINGER, P. Desenvolvimento econômico e evolução urbana. Análise da evolução econômica de São Paulo, Blumenau, Porto Alegre, Belo Horizonte e Recife. São Paulo: Companhia Editora Nacional, 1968.

VILlAÇA, F. Espaço intra-urbano no Brasil. São Paulo: Studio Nobel/Lincoln Institute, 2001.

Maria de Lourdes Jardim: Estatística, Mestre em Demografia, Técnica da Fundação de Economia e Estatística.

Tanya M. de Barcellos: Socióloga, Mestre em Sociologia, Técnica da Fundação de Economia e Estatística.

Artigo recebido em 30 de maio de 2005 .

Aprovado em 29 de agosto de 2005. 